\title{
SOLUTION OF A FIRST-ORDER NON-LINEAR DIFFERENTIAL EQUATION IN CHEBYSHEV SERIES
}

1. Procedure declaration. Procedure nldiffeqNort calculates the approximate values of the coefficients of the Chebysher series expansion (i.e. the series of Chebysher polynomials $T_{k}$ of the first kind) of the solution of the differential equation

$$
y^{\prime}=f(x, y) \quad(-1 \leqslant x \leqslant 1)
$$

with the initial condition

$$
y(\beta)=\gamma
$$

or the boundary condition

$$
\alpha y(-1)+\beta y(1)=\gamma,
$$

i.e. it calculates the coefficients $a_{k}(k=0,1, \ldots, n ; n \leqslant N)$ such that

$$
y(x) \approx \sum_{k=0}^{n} a_{k} T_{k}(x) \quad(-1 \leqslant x \leqslant 1)
$$

The symbol $\Sigma^{\prime}$ in (4) denotes summation with the first summand halved:

$$
\sum_{k=0}^{n} t_{k}=\frac{1}{2} t_{0}+t_{1}+\ldots+t_{n}
$$

Data:

$n$ - integer variable, with value not less than 4 and even, denoting the trial value of the upper summation limit in (4);

$a[0: n]$ - array of trial values of the coefficients in $(4)\left(a[k]=a_{k}\right.$ for $k=0,1, \ldots, n)$ determining a polynomial satisfying either (2) or (3);

$n \max$ - even natural number $N \geqslant 4$, the maximum permissible value of $n$; 
$s$ - non-negative integer number, the degree of the polynomial approximating the function $f_{y}(x, y(x))$ (see Section 2, formula (13));

init - true if the solution satisfies the initial condition (2), and false if the solution satisfies the boundary condition (3);

$f f y$ - identifier of the procedure having 4 parameters $x, y$ (called by value), $f, f y$ of type real, which for given $x$ and $y$ assigns to $f$ the value of $f(x, y)$ and to $f y$ the value of the partial derivative $f_{y}(x, y)$;

$a l, b e, g a$ - numbers $\alpha, \beta$ and $\gamma$ from (2) and (3); in case (2) the value of $a l$ is arbitrary;

eps - positive number $\varepsilon$ characterizing the permissible absolute error of $a_{k}$ (see Section 2, inequalities (39) and (40));

maxit - maximum permissible number of iterations $R$ in the auxiliary iteration process (see Section 2, relation (17));

Chebval - real procedure identifier with parameters $n$ of type integer, $a$ of type array, and $x$ of type real, the value of which for given $n, a$ and $x$ is the sum in (4) (see, e.g., [9]).

Remark. The declaration of the array $a$ should be at least $[0: n \max +1]$.

Results:

$n$ - upper summation limit of the right-hand side of (4);

$a[0: n]$ - array of the coefficients giving a sufficiently good approximation of the solution of equation (1);

maxit - number of calculated approximations of the solution of equation (1) (see Section 2, formula (5)).

Other parameters:

ns - label of the instruction (outside of the procedure body) to which a jump is made in the case where it is not possible to calculate the solution;

mark - integer variable whose value is determined only if a jump to label $n s$ has been made; mark $=1$ indicates that $n$ max was too small to achieve the desired accuracy, and mark $=2$ indicates that after maxit iterations the auxiliary iteration process led to a solution which did not have the desired accuracy.

2. Method used. The following variant of Norton's method [5] has been used. A sequence of approximations $\left\{y_{i}\right\}$ of the solution of either problem (1), (2) or problem (1), (3) is determined. The function $y_{0}$ is arbitrary (e.g. a polynomial) provided it satisfies (2) or (3), respectively, and $y_{i}(i=1,2, \ldots)$ is the solution of the linear differential equation

$$
\frac{d y_{i}}{d x}=f\left(x, y_{i-1}\right)+\left(y_{i}-y_{i-1}\right) f_{y}\left(x, y_{i-1}\right)
$$


arecedure nldiffeqiort $(n, A, n \max , 8$, int $, f f y, a l$, be, $89, e p s$, naxit, (nebval, ne, mark);

yelue rimax, $8, a 1$, be; ga;

integer $n$, nmax, o, maxit, mark;

real al, be, ga, epв;

Boolean in1t;

arcey 8;

label ns;

real 2rocedure Chebval;

arocedure ffy;

becin

integer $1, i t, 11, i 2,13,14, k, k 1, k 2, m, n c, n c 4$;

real ab,ak, akm1, akp1, bk, bkm1, bkp1, cn, c1, eps1, ga2, gk, h:b.

$k 4,0 x, r c 0, r c 4, r m, 81,82, t, t r n, w k, x 0, x 1, x^{2}, z k$;

Boolean bco, sgto;

axney $b, d, q, x[0: n \max ], c[028], g, w, z[1: n \max ]$;

$\mathrm{nc}:=\mathrm{n}$;

$\mathrm{n}:=\mathrm{nc}+1$;

if init

then $g a 2:=-g a-g a$

else

begin

$$
\begin{array}{r}
\text { ab: }=a l+b e ; \\
h a b:=.5 \times a b \\
\text { end } \neg \text { init; }
\end{array}
$$

for $k:=n$ step 1 unt 11 nmax do

$$
\begin{aligned}
& a[k]:=b[k]:=.0 ; \\
& \text { eps1: }=.1 \times \text { eps; } \\
& \text { nmax: }=\text { nmax }-1 ; \\
& \text { sgto: }=8>0 ;
\end{aligned}
$$




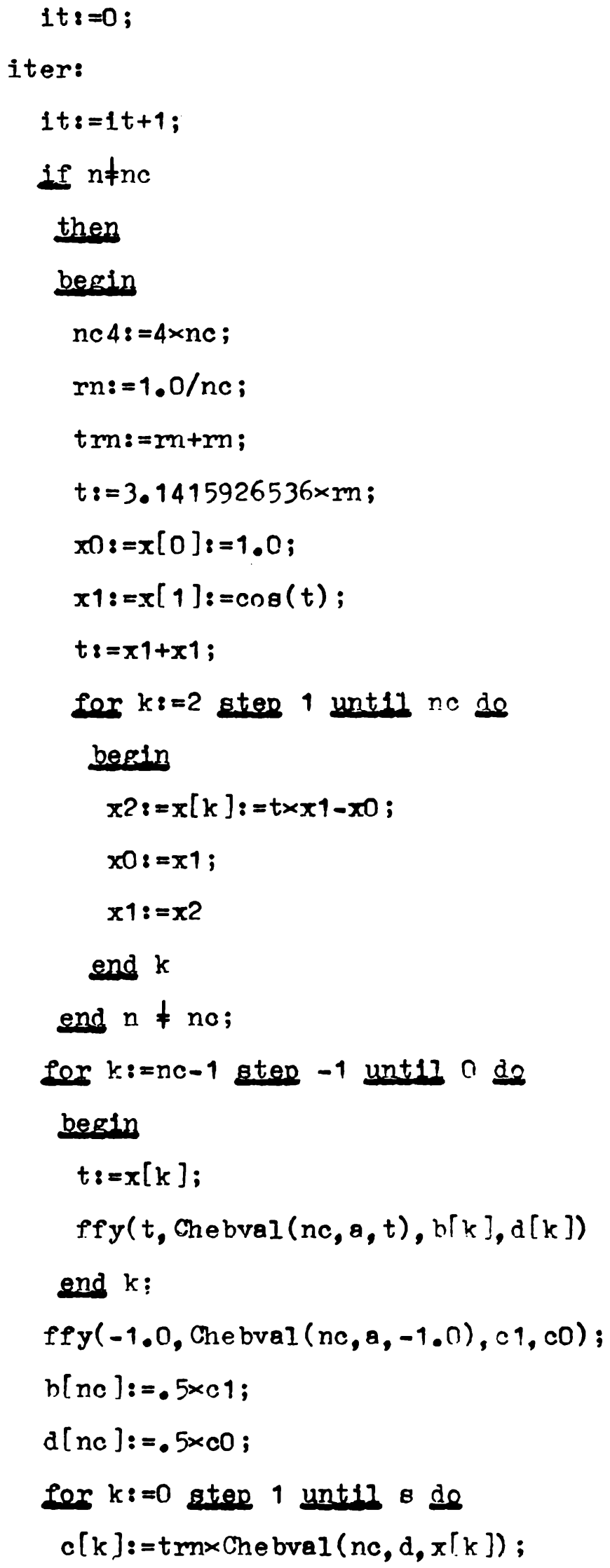




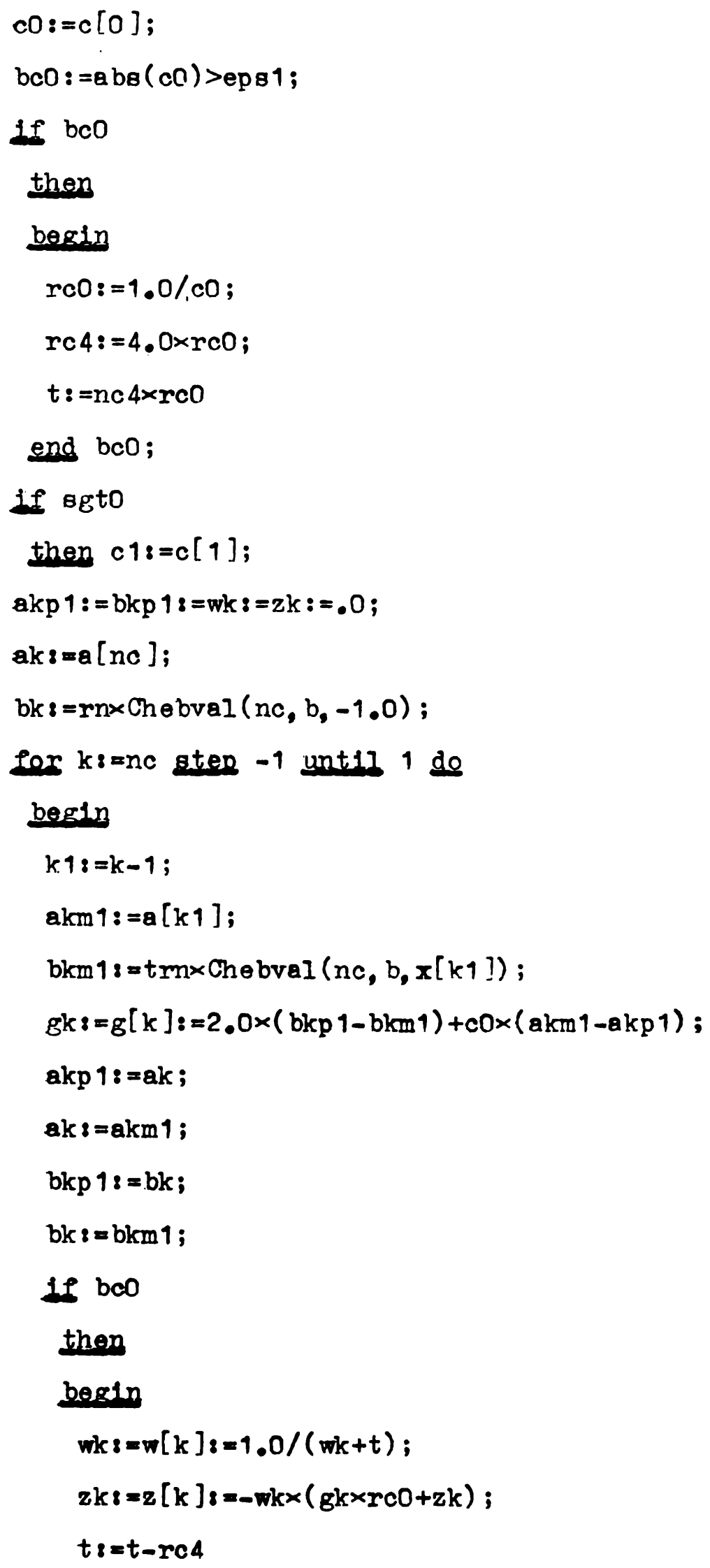




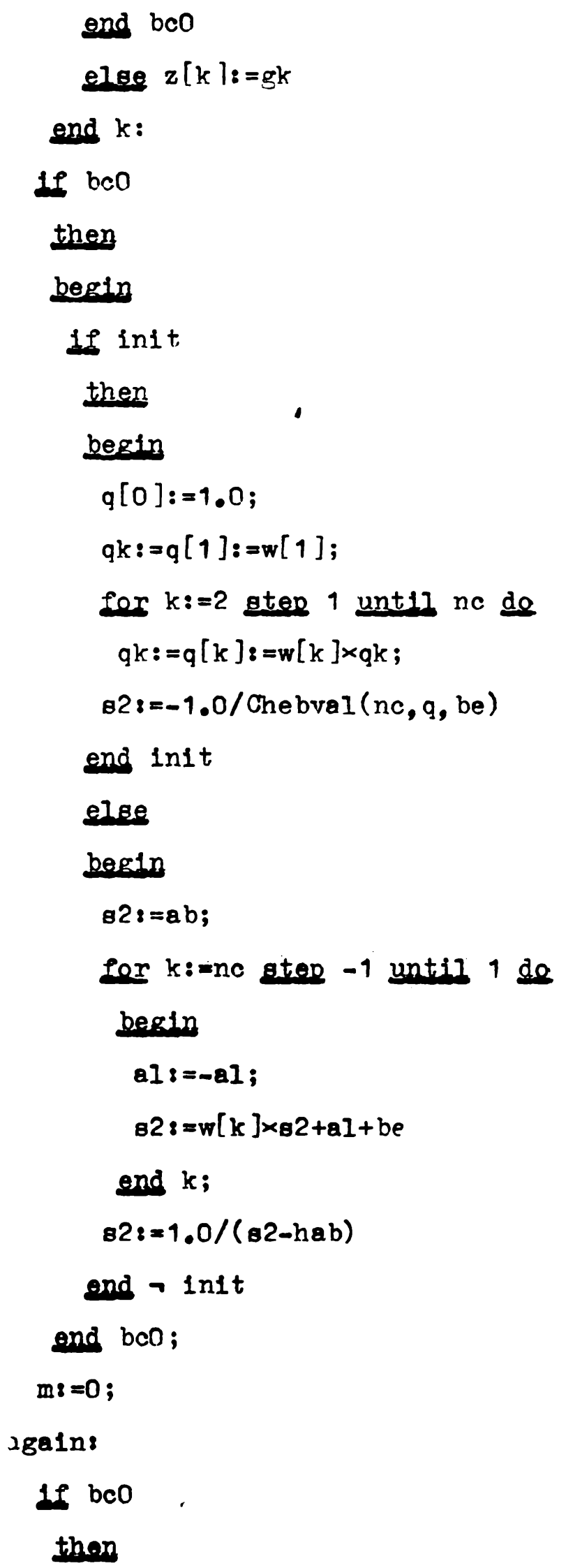


begin

if init

then

begin

$q[0]:=g a 2 ;$

$q k s=q[1] s=z[1]$;

for $k:=2$ step 1 until nc do

$q k:=q[k]:=w[k] \times q k+z[k] ;$

bk: $=\mathrm{b}[0]:=$ Chebral $(\mathrm{nc}, \mathrm{q}, \mathrm{be}) \times \otimes 2$

end Inft

else

begin

$818=8 a ;$

$t:=.0$;

Lor $k:=1$ step 1 until no do

besing

als=-al;

$t:=t \times w[k]+z[k]$;

$818=81-t \times\left(a 1+b_{e}\right)$

end k;

$\mathrm{bk} \&=b[0]:=81 \times 82$

end 7 init;

for $k s=1$ step 1 unt 11 ne do

$b k:=b[k]:=w[k] \times b k+z[k]$

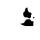

end bco

else

begin

$k 48=-4.0 ;$

Lor k:=1 step 1 until no do

begin 


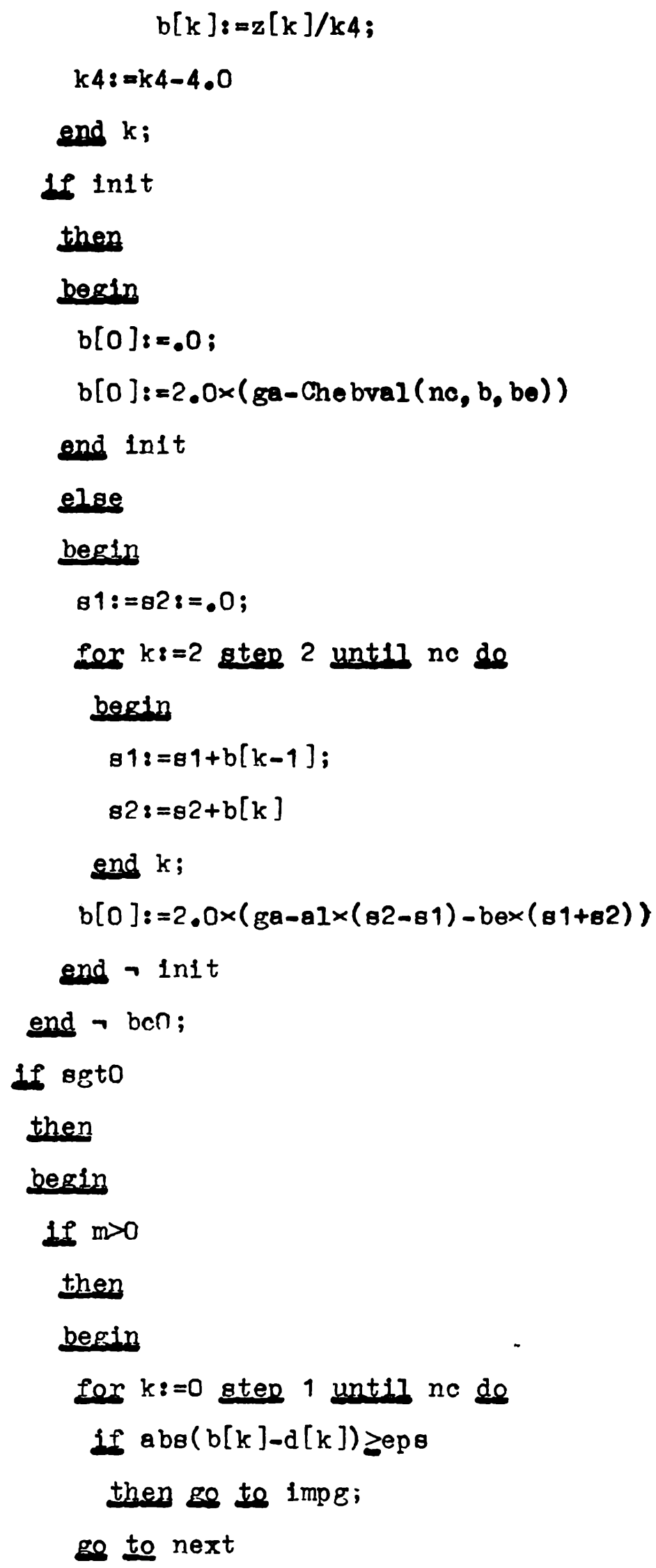


end $m>0$;

imp g:

$$
\begin{aligned}
& m:=m+1 ; \\
& \text { If } m>\operatorname{maxit}
\end{aligned}
$$

then

begin

merk: $=2$;

so to ns

end $m>\operatorname{maxit}$;

$2 k 8=.0$;

for $k:=n c$ step -1 unt il 1 do

begin

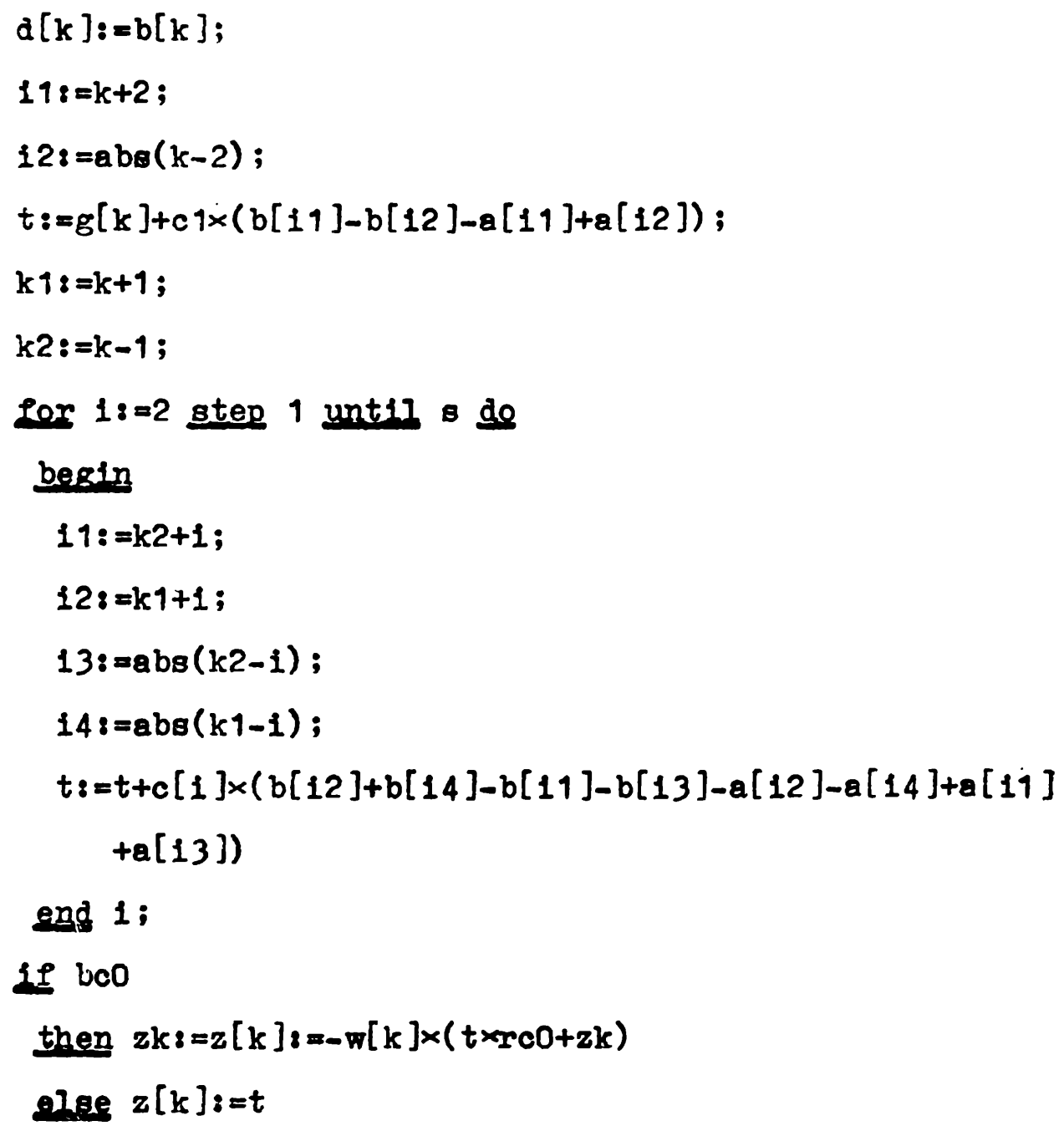




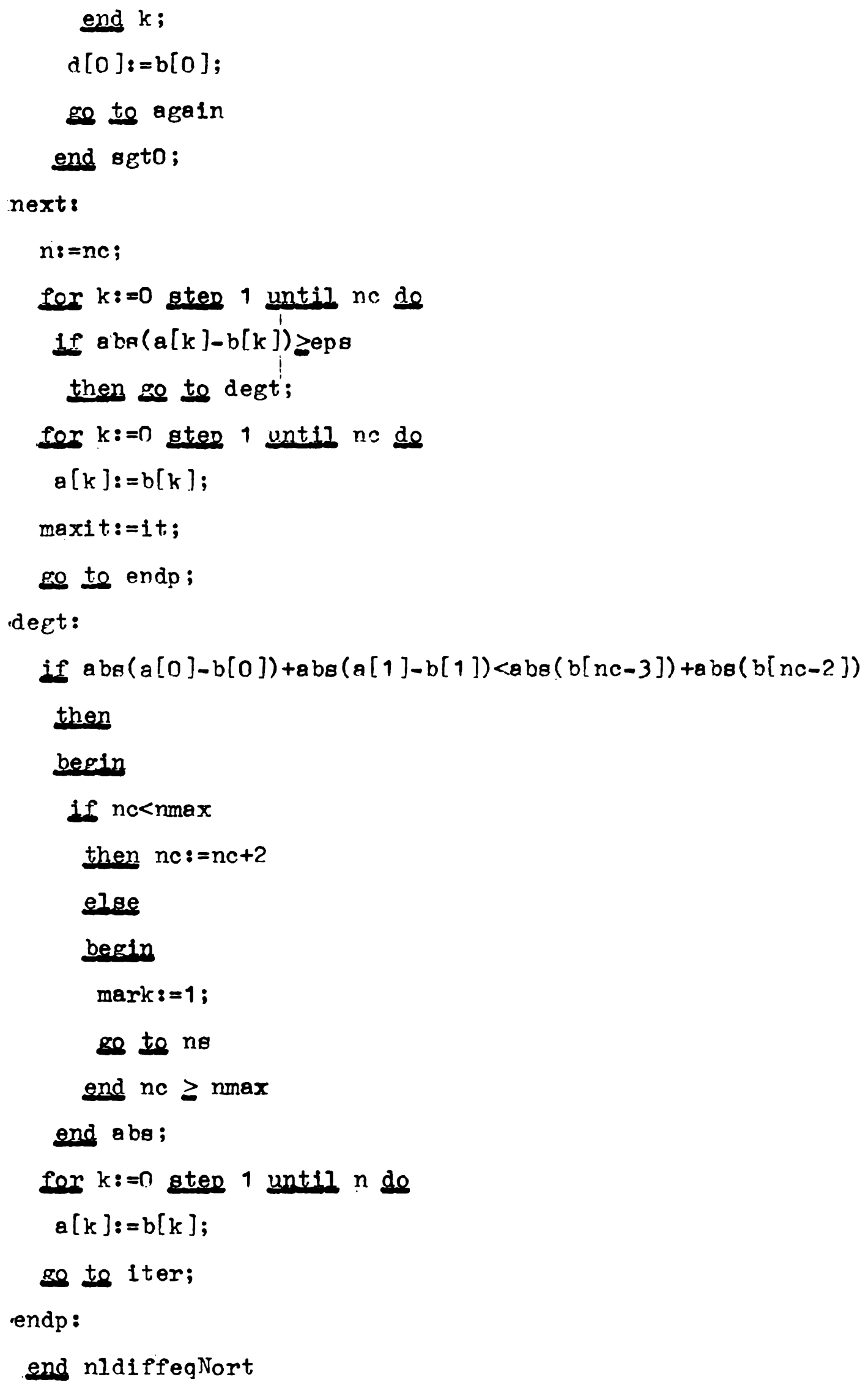


with the condition

$$
y_{i}(\beta)=\gamma
$$

or

$$
\alpha y_{i}(-1)+\beta y_{i}(1)=\gamma,
$$

in accordance with the condition posed upon the solution of (1).

Assume that all functions appearing in (5) can be expanded into Chebysher series and let

$$
\begin{gathered}
y_{i}(x)=\sum_{k=0}^{\infty} A_{k}^{(i)} T_{k}(x), \\
\frac{d y_{i}(x)}{d x}=\sum_{k=0}^{\infty} A_{k}^{\prime(i)} T_{k}(x), \\
f\left(x, y_{i-1}(x)\right)=\sum_{k=0}^{\infty} b_{k}^{(i)} T_{k}(x), \\
f_{y}\left(x, y_{i-1}(x)\right)=\sum_{k=0}^{\infty} c_{k}^{(i)} T_{k}(x) .
\end{gathered}
$$

To facilitate the notation we omit the upper index $i$ in the coefficients of these series and write $a_{k}$ instead of $A_{k}^{(i-1)}$. Thus

$$
y_{i-1}(x)=\sum_{k=0}^{\infty} a_{k} T_{k}(x) .
$$

Let $s \geqslant 0$. Instead of the exact formula (11) we use the approximation

$$
f_{y}\left(x, y_{i-1}(x)\right) \approx \sum_{k=0}^{s} c_{k} T_{k}(x)
$$

The approximate values of the coefficients $b_{k}$ and $c_{k}$ of expansions (10) and (13), respectively, for the given function $y_{i-1}(x)$ can be obtained by the method described in [2], Section 4.

Replacing in (5) the functions $y_{i}, d y_{i} / d x, f\left(x, y_{i-1}\right), y_{i-1}$ and $f_{y}\left(x, y_{i-1}\right)$ by the right-hand sides of (8)-(10), (12) and (13), respectively, and using the relations (see, e.g., [1])

$$
\begin{gathered}
2 k A_{k}=A_{k-1}^{\prime}-A_{k+1}^{\prime} \quad(k=1,2, \ldots), \\
2 T_{p}(x) T_{q}(x)=T_{p+q}(x)+T_{|p-q|}(x) \quad(p, q=0,1, \ldots),
\end{gathered}
$$

we obtain the equation

$$
c_{0} A_{k-1}-4 k A_{k}-c_{0} A_{k+1}=g_{k} \quad(k=1,2, \ldots),
$$


where

$$
+\sum_{j=1}^{s} c_{j}\left(d_{k+j+1}+d_{k-j+1}-d_{k+j-1}-d_{|k-j-1|}\right), \quad d_{p}=A_{p}-a_{p} \quad(p \geqslant 0) .
$$

By (6) we can obtain the relation

$$
\sum_{k=0}^{\infty} \tau_{k} A_{k}=\gamma
$$

where $\tau_{k}=T_{k}(\beta)$. In case of condition (7) relation (16) holds also for $\tau_{k}=(-1)^{k} \alpha+\beta$.

In [5] an iterative method of solution of problem (14)-(16) is proposed. If we take $A_{0 k}=a_{k}$, we can construct sequences $\left\{A_{r k}\right\}(r=1,2, \ldots)$ such that

$$
c_{0} A_{r, k-1}-4 k A_{r k}-c_{0} A_{r, k+1}=g_{r k} \quad(r, k=1,2, \ldots),
$$

where $g_{r k}$ denotes the right-hand side of the first formula of (15) in which it was assumed $d_{p}=A_{r-1, p}-a_{p}(p \geqslant 0)$; in addition, we have

$$
\sum_{k=0}^{\infty} \tau_{k} A_{r k}=\gamma \quad(r=1,2, \ldots)
$$

For a fixed $r$ the problem lies in solving the difference equation of the second order

$$
c_{0} \alpha_{k-1}-4 k \alpha_{k}-c_{0} \alpha_{k+1}=\gamma_{k} \quad(k=1,2, \ldots) ;
$$

where $\gamma_{k}=g_{r k}$ with the condition

$$
\sum_{k=0}^{\infty} \tau_{k} \alpha_{k}=\gamma
$$

The case $c_{0}=0$ is trivial. Assume now $c_{0} \neq 0$. Notice that the homogeneous equation

$$
c_{0} \alpha_{k-1}-4 k \alpha_{k}-c_{0} \alpha_{k+1}=0 \quad(k=1,2, \ldots)
$$

has a general solution of the form

$$
C_{1} \sigma^{k} I_{k}\left(\frac{\left|c_{0}\right|}{2}\right)+C_{2}(-\sigma)^{k} K_{k}\left(\frac{\left|c_{0}\right|}{2}\right) \quad\left(\sigma=\operatorname{sign} c_{0}\right)
$$

where $I_{k}$ and $K_{k}$ are modified Bessel functions of the first and second kind, respectively, and where $C_{1}$ and $C_{2}$ are arbitrary constants. 
Since for $k \rightarrow \infty$

$$
I_{k}(t) \rightarrow 0 \quad \text { and } \quad K_{k}(t) \rightarrow \infty
$$

thus $\sigma^{k} I_{k}\left(\left|c_{0}\right| / 2\right)$ is the minimal solution and $(-\sigma)^{k} K_{k}\left(\left|c_{0}\right| / 2\right)$ is the dominating solution of (21) (see [3], Introduction). Applying the results obtained by Oliver [8] we see that the solution of problem (19), (20) is of the form

$$
\alpha_{k}=C \sigma^{k} I_{k}\left(\frac{\left|c_{0}\right|}{2}\right)+\psi_{k}
$$

where $C$ is an appropriate constant and $\psi_{k}$ is a particular solution of (19) such that $\psi_{k} \rightarrow 0$ as $k \rightarrow \infty$.

In [5] the approximate solution $\alpha_{k}^{(n)}$ ( $n$ sufficiently large) is constructed with the help of the formulas

$$
\alpha_{k}^{(n)}=C \varphi_{k}^{(n)}+\psi_{k}^{(n)} \quad(k=1,2, \ldots, n),
$$

where

$$
\varphi_{n+1}^{(n)}=0, \quad \varphi_{n}^{(n)}=1, \quad \varphi_{k-1}^{(n)}=\varphi_{k+1}^{(n)}+4 k \varphi_{k}^{(n)} / c_{0} \quad(k=n, n-1, \ldots, 1)
$$

and

$$
\begin{array}{r}
\psi_{n+1}^{(n)}=\psi_{n+2}^{(n)}=0, \quad \psi_{k-1}^{(n)}=\psi_{k+1}^{(n)}+\left(4 k \psi_{k}^{(n)}+\gamma_{k}\right) / c_{0} \\
(k=n+1, n, \ldots, 1),
\end{array}
$$

and the constant $C$ is determined in such a manner that the following condition holds:

$$
\sum_{k=0}^{n} \tau_{k} \alpha_{k}^{(n)}=\gamma
$$

Hence

$$
C=\left(\gamma-\sum_{k=0}^{n} \tau_{k} \psi_{k}^{(n)}\right) / \sum_{k=0}^{n} \tau_{k} \varphi_{k}^{(n)}
$$

Formulae (23) describe the algorithm of Miller (backward recurrence algorithm) for equation (21). In view of Theorem 3.1 from [3], for a fixed $k$ we have

$$
\varphi^{(n)} \rightarrow \varphi_{k} \quad(\text { as } n \rightarrow \infty),
$$

where $\varphi_{k}$ is the minimal solution of equation (21) which differs from $\sigma^{k} I_{k}\left(\left|c_{0}\right| / 2\right)$ only by a constant.

The algorithm given by (22)-(25) appears to have a strong non-stability when with the increasing $k$ the value of $\left|\alpha_{k}\right|$ decreases significantly 
slowlier than $I_{k}\left(\left|c_{0}\right| / 2\right)$ (see [6], Section 13). Also, it is known ([7] and [8]) that replacing the initial problem (19), (20) by an appropriate boundary problem leads to stability.

Assume that the system of linear equations

$$
\begin{gathered}
c_{0} \alpha_{k-1}^{(n)}-4 k \alpha_{k}^{(n)}-c_{0} \alpha_{k+1}^{(n)}=\gamma_{k} \quad(k=1,2, \ldots, n), \\
\alpha_{n+1}^{(n)}=0, \\
\sum_{k=0}^{n} \tau_{k} \alpha_{k}^{(n)}=\gamma
\end{gathered}
$$

has the solution $a_{0}^{(n)}, a_{1}^{(n)}, \ldots, \alpha_{n}^{(n)}$ for all sufficiently large $n$. One can prove ([8], Section 9) that, provided additional conditions are satisfied, the relation

holds.

$$
\alpha_{k}^{(n)} \rightarrow \alpha_{k} \quad \text { for fixed } k \text { and } n \rightarrow \infty
$$

We propose the following method of solving (26)-(28). First, using (27) in the last $(k=n)$ equation of system (26), we obtain a relation of the form

$$
\alpha_{n}^{(n)}=W_{n}^{(n)} \alpha_{n-1}^{(n)}+Z_{n}^{(n)},
$$

where $W_{n}^{(n)}=c_{0} / 4 n$ and $Z_{n}^{(n)}=-\gamma_{n} / 4 n$. Using the last but one $(k=n-1)$ equation of system (26) and also equation (29) to the elimination of unknown $\alpha_{n}^{(n)}$, we obtain the equation

$$
\alpha_{n-1}^{(n)}=W_{n-1}^{(n)} \alpha_{n-2}^{(n)}+Z_{n-2}^{(n)},
$$

where

$$
W_{n-1}^{(n)}=\frac{c_{0}}{c_{0} W_{n}^{(n)}+4(n-1)} \quad \text { and } \quad Z_{n-1}^{(n)}=-\frac{\gamma_{n-1}+c_{0} Z_{n}^{(n)}}{c_{0} W_{n}^{(n)}+4(n-1)}
$$

Continuing this elimination leads us to a system being equivalent to system (26), (27)

$$
\alpha_{k}^{(n)}=W_{k}^{(n)} \alpha_{k-1}^{(n)}+Z_{k}^{(n)} \quad(k=1,2, \ldots, n),
$$

where

$$
\begin{aligned}
& W_{k}^{(n)}=\frac{c_{0}}{c_{0} W_{k+1}^{(n)}+4 k} \quad\left(k=n, n-1, \ldots, 1 ; W_{n+1}^{(n)}=0\right), \\
& Z_{k}^{(n)}=-\frac{\gamma_{k}+c_{0} Z_{k+1}^{(n)}}{c_{0} W_{k+1}^{(n)}+4 k} \quad\left(k=n, n-1, \ldots, 1 ; Z_{n+1}^{(n)}=0\right) .
\end{aligned}
$$

Using (30) it is possible to derive (by induction) the relation

$$
\alpha_{k}^{(n)}=p_{k}^{(n)} \alpha_{0}^{(n)}+q_{k}^{(n)} \quad(k=1,2, \ldots, n),
$$


where

$$
\begin{aligned}
& p_{0}^{(n)}=1, \quad p_{k}^{(n)}=W_{k}^{(n)} p_{k-1}^{(n)}, \\
& q_{0}^{(n)}=0, \quad q_{k}^{(n)}=W_{k}^{(n)} q_{k-1}^{(n)}+Z_{k}^{(n)}
\end{aligned} \quad(k=1,2, \ldots, n) .
$$

This and (28) lead to the formula

$$
a_{0}^{(n)}=\left(\gamma-\sum_{k=1}^{n} \tau_{k} q_{k}^{(n)}\right) / \sum_{k=0}^{n} \tau_{k} p_{k}
$$

From (30) (or (33)) one can successively calculate $\alpha_{1}^{(n)}, \alpha_{2}^{(n)}, \ldots, \alpha_{n}^{(n)}$.

Let us now investigate the accumulation of the rounding errors during the realization of algorithm (30)-(35). We have by (31) the formula

$$
W_{k}^{(n)}=\frac{c_{0}}{4 k}+\frac{c_{0}^{2}}{4(k+1)}+\ldots+\frac{c_{0}^{2}}{4 n} .
$$

Applying the known theorem of Pincherle (see, e.g., [3], Section 1) for fixed $k$ we have

$$
\lim _{n \rightarrow \infty} W_{k}^{(n)}=\varphi_{k} / \varphi_{k-1}
$$

where $\varphi_{k}$ is the minimal solution of (21). Therefore, for sufficiently large $n$ we obtain

$$
\left|W_{k}^{(n)}\right| \approx I_{k}\left(\frac{\left|c_{0}\right|}{2}\right) / I_{k-1}\left(\frac{\left|c_{0}\right|}{2}\right),
$$

from which it follows that $W_{k}^{(n)}$, whence also the rounding errors arising during the calculation, cannot increase rapidly.

It follows from (36) that $W_{k}^{(n)}$ and $c_{0}$ are of equal sign, and hence the denominators of the fractions in (31) and (32) are sums of two positive summands with the order $4 k$. Stability can be lost by the multiple loss of significant places during the calculation of $\gamma_{k}+c_{0} Z_{k+1}^{(n)}$ for $n=n, n-1$, $\ldots, 1$. This has as yet not been observed in practice.

Now, it follows that the calculation of $p_{k}^{(n)}$ and $q_{k}^{(n)}$ is stabile. Loss of accuracy is, however, possible during the calculation of $\alpha_{0}^{(n)}$ after formula (35) which, in turn, causes a small accuracy of all $\alpha_{k}^{(n)}(k=1,2, \ldots, n)$. This fact can be observed, e.g., when the expression $\left|\frac{1}{2} \tau_{0}+\sigma^{(n)}\right|$, where

$$
\sigma^{(n)}=\sum_{k=1}^{n} \tau_{k} p_{k}^{(n)}
$$

is small with respect to $\frac{1}{2}\left|\tau_{0}\right|$. Notice that $p_{k}^{(n)}=W_{1}^{(n)} W_{2}^{(n)} \ldots W_{k}^{(n)}$ (see the first formula of (34)). Therefore from (37) we obtain

$$
\sigma^{(n)}=\sum_{k=1}^{n} \tau_{k} W_{1}^{(n)} W_{2}^{(n)} \ldots W_{k}^{(n)} \approx \frac{1}{I_{0}\left(\left|c_{0}\right| / 2\right)} \sum_{k=1}^{n} \tau_{k} \sigma^{k} I_{k}\left(\frac{\left|c_{0}\right|}{2}\right) .
$$


In view of

$$
e^{c x}=2 \sum_{k=0}^{\infty}(\operatorname{sign} c)^{k} I_{k}(|c|) T_{k}(x) \quad(-1 \leqslant x \leqslant 1)
$$

(see, e.g., [4], p. 32), for the initial problem (1), (2) we have

$$
\sigma^{(n)} \approx \frac{1}{2 I_{0}\left(\left|c_{0}\right| / 2\right)}\left[\exp \left(\frac{1}{2} c_{0} \beta\right)-I_{0}\left(\frac{\left|c_{0}\right|}{2}\right)\right]
$$

and for the boundary problem (1), (3) we obtain

$$
\sigma^{(n)} \approx \frac{1}{2 I_{0}\left(\left|c_{0}\right| / 2\right)}\left\{\alpha\left[\exp \left(-\frac{1}{2} c_{0}\right)-I_{0}\left(\frac{\left|c_{0}\right|}{2}\right)\right]+\beta\left[\exp \left(\frac{1}{2} c_{0}\right)-I_{0}\left(\frac{\left|c_{0}\right|}{2}\right)\right]\right\} .
$$

Thus $\left|\left(\frac{1}{2} \tau_{0}+\sigma^{(n)}\right) / \frac{1}{2} \tau_{0}\right|$ is small if

$$
\left[\exp \left(\frac{1}{2} c_{0} \beta\right)\right] / 2 I_{0}\left(\frac{\left|c_{0}\right|}{2}\right) \quad \text { or } \quad\left|\alpha \exp \left(-\frac{1}{2} c_{0}\right)+\beta \exp \left(\frac{1}{2} c_{0}\right)\right| / 2 I_{0}\left(\frac{\left|c_{0}\right|}{2}\right)
$$

respectively, are small. In practice, however, the value of each of these expressions is of moderate order.

The above-described method of solving the problem (19), (20) is a generalization of the so-called first algorithm of Gautschi ([3], Section 3) of solving a homogeneous difference equation of the order two. In fact, if in (19) $\gamma_{k} \equiv 0$ holds, then from (32) and from the second line of (34) it follows that $Z_{k}^{(n)}=q_{k}^{(n)}=0$ for $k=1,2, \ldots, n$, and formulae (30)-(35) are reduced to the form

$$
\begin{aligned}
\alpha_{k}^{(n)} & =W_{k}^{(n)} \alpha_{k-1}^{(n)} \\
W_{k}^{(n)} & =\frac{c_{0}}{c_{0} W_{k+1}^{(n)}+4 k} \quad(k=1,2, \ldots, n), \\
\alpha_{0}^{(n)} & =\frac{\gamma}{\frac{1}{2} \tau_{0}+\sigma^{(n)}},
\end{aligned}
$$

where $\sigma^{(n)}$, defined by (38), can be calculated from the formulae

$$
\begin{aligned}
& \sigma_{k}^{(n)}=W_{k}^{(n)}\left(\tau_{k}+\sigma_{k+1}^{(n)}\right) \quad\left(k=n, n-1, \ldots, 1 ; \sigma_{n+1}^{(n)}=0\right), \\
& \sigma^{(n)}=\sigma_{1}^{(n)} .
\end{aligned}
$$

These formulae are to be compared with system (3.9) in [3].

Problem (17), (18) is solved by use of (30)-(35) for $r=1,2, \ldots$, $r_{0} \leqslant R$, where $r_{0}$ is the smallest natural number such that

$$
\max _{0 \leqslant k \leqslant n}\left|A_{r_{0} k}-A_{r_{0}-1, k}\right|<\varepsilon
$$


where $\varepsilon$ is a given positive number. Next, let us take $A_{k}^{(i)}=A_{r_{0} k}$ for $k=0,1, \ldots, n$.

If the inequality

$$
\max _{0 \leqslant k \leqslant n}\left|A_{k}^{(i)}-A_{k}^{(i-1)}\right|<\varepsilon
$$

holds, then $A_{k}^{(i)}(k=0,1, \ldots, n)$ are the required coefficients of the sum in (4). Otherwise,

$1^{\circ}$ if the inequality

$$
\left|A_{0}^{(i)}-A_{0}^{(i-1)}\right|+\left|A_{1}^{(i)}-A_{1}^{(i-1)}\right|<\left|A_{n-2}^{(i)}\right|+\left|A_{n-3}^{(i)}\right|
$$

holds, then we increase $n$ by 2 (see [2]) and forth.

$2^{\circ}$ we proceed to the calculation of $A_{k}^{(i+1)}(k=0,1, \ldots, n)$, and so

Certification. The procedure has been verified on the Odra 1204 computer for the following problems:

$$
\begin{aligned}
& y^{\prime}=y^{2}, y(-1)=0.4 \quad(\text { solution } y=2 /(3-2 x)) \\
& y^{\prime}=x-y^{2}, y(0)=-0.729011132947
\end{aligned}
$$

(solution $y=\operatorname{Ai}^{\prime}(x) / \operatorname{Ai}(x)$, where $\operatorname{Ai}(x)=\frac{1}{\pi} \int_{0}^{\infty} \cos \left(\frac{1}{3} t^{3}+x t d t\right)$ );

(43) $\quad y^{\prime}=\sin y, y(-1)=\arccos \tanh 1$

(solution $y=\arccos (-\tanh x)$ ),

$$
y^{\prime}=1-\sqrt{|y|}+\cos \pi x, y(-1)-y(1)=0 \quad(\text { see [5], Section } 7) \text {. }
$$

It was assumed that $y_{0}(x) \equiv \gamma$ in problems $(41)-(43)$ and that $y_{0}(x) \equiv 1$ in problem (44). The results for $\varepsilon=5_{10}-9, n \max =100$ and maxit $=50$ were as follows:

\begin{tabular}{c|c|c|c|c|c} 
Problem & $n$ given & $s$ & $\begin{array}{c}\text { Iteration } \\
\text { number }\end{array}$ & $\begin{array}{c}n \\
\text { calculated }\end{array}$ & $10^{10} \Delta$ \\
\hline$(41)$ & 20 & 0 & 14 & 24 & 13 \\
& & 2 & 9 & 22 & 12 \\
$(42)$ & 14 & 0 & 10 & 16 & 5 \\
& & 2 & 5 & 16 & 10 \\
$(43)$ & 16 & 0 & 10 & 16 & 7 \\
& & 1 & 7 & 18 & 11 \\
$(44)$ & 22 & 0 & 6 & 22 & 16 \\
& & 2 & 6 & 22 & 6 \\
& & 3 & 5 & 22 & 19
\end{tabular}

The last column contains the maximum absolute error of the calculated coefficient values, multiplied by $10^{10}$. 


\title{
References
}

[1] C. W. Clenshaw, The numerical solution of linear differential equations in Chebysh series, Proc. Cambridge Phil. Soc. 53 (1957), p. 134-149.

[2] - and H. J. Norton, The solution of non-linear ordinary differential equation in Chebyshev series, Comp. J. 6 (1963), p. 88-92.

[3] W. Gautschi, Computational aspects of three-term recurrence relations, SIA Rev. 9 (1967), p. 24-82.

[4] Y. L. Luke, The special functions and their approximations, New York 1969.

[5] H. J. Norton, The iterative solution of non-linear ordinary differential equation in Chebyshev series, Comp. J. 7 (1964), p. 76-85.

[6] J. Oliver, Relative error propagation in the recursive solution of linear recurren relations, Numer. Math. 9 (1967), p. 323-340.

[7] - The numerical solution of linear recurrence relations, ibidem 11 (1968), p. 349-36

[8] F. W. J. Olver, Numerical solution of second-order linear difference equation J. Res. NBS 71 B (1967), p. 111-129.

[9] S. Paszkowski, Procedure Chebval, in The library of ALGOL programs and pr. cedures of the Odra 1204 computer, Elwro, Wrocław 1970 (in Polish).

INSTITUTE OF INFORMATICS

UNIVERSITY OF WROCEAW

50-384 WROCEAW

Received on 5. 3. 1975

S. LEWANOWICZ (Wroelaw)

ALGORYTM

ROZWIAZZANIE NIELINIO WEGO RÓWNANIA RÓŻNICZKOWEGO ZWYCZ A'NEGO PIER WSZEGO RZĘDU ZA POMOCA SZEREGóW CZEBYSZE W

\author{
STRESZCZENIE
}

Procedura nldiffeqNort oblicza przybliżone wartości współczỳnników rozw nięcia w szereg Czebyszewa (szereg względem wielomianów Czebyszewa $T_{k}$ I rodzajı rozwiązania równania różniczkowego (1) $\mathrm{z}$ warunkiem początkowym (2) lub z warur kiem brzegowym (3), tj. oblicza współczynniki $a_{k}(k=0,1, \ldots, n ; n \leqslant N)$, tak że zachodzi równość przyblłżona (4), w której symbol $\Sigma^{\prime}$ oznacza sumę z pierwszy] składnikiem podzielonym przez 2.

Dane:

$n$ - zmienna, której wartością jest liczba naturalna parzysta nie mniejsz od 4, próbna wartość granicy sumowania w (4);

$a[0: n]$ - tablica próbnych wartości współczynników $\mathrm{W}(4) \quad\left(a[k]=a_{k} \mathrm{~d}\right]$ $k=0,1, \ldots, n)$, określających wielomian, który spełnia odpowiedni warunek (2) lub (3);

nmax - liczba naturalna parzysta $N \geqslant 4$, największa dopuszczalna wartość $r$

8 - liczba całkowita nieujemna, stopień wielomianu aproksymująceg funkcje $f_{\nu}(x, y(x))$ (zobacz rozdz. 2, wzór (13)); 
init - true, gdy rozwiązanie ma spełniać warunek początkowy (2), false, gdy ma spełniać warunek brzegowy (3);

$f f y$ - nazwa procedury z czterema parametrami $x, y$ (umieszczonymi w zbiorze wartości), $f, f y$ typu real, podstawiającej dla danych $x, y$ wartość $f(x, y)$ pod $f$ i wartość pochodnej cząstkowej $f_{y}(x, y)$ pod $f y$;

$a l, b e, g a$ - liczby $a, \beta, \gamma$ występujące w (2) i (3), w wypadku (2) al jest dowolne;

eps - liczba dodatnia $\varepsilon$, charakteryzująca dopuszczalny błąd bezwzględny współczynników $a_{k}$ (zobacz rozdz. 2, nierówności (39) i (40));

maxit - zmienna, której wartością jest największa dopuszczalna liczba iteracji w metodzie przybliżonego rozwiązywania układu liniowego spełnianego przez współczynniki $a_{k}$ (zobacz rozdz. 2, relacja (17));

Chebval - nazwa funkcji rzeczywistej z trzema parametrami: $n$ typu integer, $a$ typu array i $x$ typu real, przyjmującej dla danych $n, a, x$ wartość równą wartości sumy występującej w (4) (zobacz np. [9]).

Uwaga. Tablica a musi mieć rozmiar co najmniej [0:nmax +1$]$.

Wyniki:

n - górna granica sumowania po prawej stronie (4);

$a[0: n]$ - tablica współczynników dających dostatecznie dobre przybliżenie rozwiązania równania (1);

maxit - liczba obliczonych kolejno przybliżeń rozwiązania równania (1) (zobacz rozdz. 2, równanie (5)).

Inne parametry:

ns - etykieta instrukcji (poza treścią procedury nldiffeqNort), do której następuje skok, gdy nie można otrzymać rozwiązania;

mark - zmienna, której wartość określa przyczynę skoku do instrukcji z etykietą $n s: \operatorname{mark}=1$, gdy $n \max$ jest za małe do osiągnięcia żądanej dokładności, mark $=2$, gdy dane maxit jest zbyt małe.

$\mathrm{W}$ procedurze nldiffeqNort zastosowano algorytm Nortona [5] z pewnymi modyfikacjami. Użytą metodę szczegółowo opisano w rozdz. 2. Wyniki obliczeń, wykonanych na maszynie cyfrowej Odra 1204, zamieszczone w rozdz. 3, wykazały poprawność algorytmu. 